\title{
Canopy structure and spatial heterogeneity of understory light in an abandoned Holm oak woodland
}

\author{
Fernando VALLADARES ${ }^{\mathrm{a} *}$, Beatriz GUZMÁN ${ }^{\mathrm{b}}$ \\ a Instituto de Recursos Naturales, Centro de Ciencias Medioambientales, C.S.I.C., Serrano 115 dpdo., 28006 Madrid, Spain, \\ Area de Biodiversidad y Conservación, ESCET Universidad Rey Juan Carlos, 28933 Mostoles Madrid, Spain

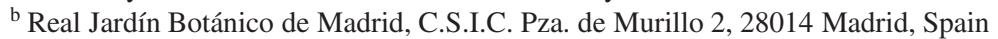

(Received 31 May 2005; accepted 27 January 2006)

\begin{abstract}
Understory light is crucial to understand forest ecology but there is scant information for Mediterranean forests. Understory light of an abandoned Holm oak (Quercus ilex L.) woodland was studied in central Spain by means of hemispherical photographies in a $30 \times 30$ grid of 1 - $\mathrm{m}^{2}$ points. Canopy height, stem density and basal area had a significant influence on understory light. Height exhibited the most significant correlation, with indirect light. However, its potential as a predictor of understory light was low due to the large fraction of unexplained variance. Sunflecks contributed to half of the understory light; they were intense and long $(25 \mathrm{~min})$, and $10 \mathrm{~min}$ shorter at the herb than at the shrub layer. Mean light availability in the understory was half of that in the open and it exhibited a significant spatial heterogeneity. Spatial grain was significantly coarser for indirect than for direct light; it was also coarser at the herb than at the shrub layer, indicating that while a single individual shrub exploits light heterogeneity via phenotypic plasticity at the shrub layer, different individuals or micropopulations exploit it at the herb layer. Abandonment of traditional management of Holm oak woodlands leads to a decrease in both the availability and the spatial heterogeneity of understory light.
\end{abstract}

hemispherical photography / Holm oak / understory light / Mediterranean forests / spatial heterogeneity

Résumé - Structure du couvert et hétérogénéité spatiale du rayonnement lumineux transmis dans une friche à chêne vert. Le rayonnement transmis sous couvert est une composante essentielle de l'écologie forestière. Malheureusement, peu d'information est disponible sur ce point dans le cas des forêts méditerranéennes. Le rayonnement lumineux transmis sous la couvert d'un peuplement de chêne vert (Quercus ilex L.) issu d'une friche a été étudié en Espagne centrale en utilisant des photographies hémisphériques prises selon une grille $30 \times 30$ de placettes de $1 \mathrm{~m}^{2}$. La hauteur des arbres, la densité du peuplement et la surface terrière modulaient fortement le rayonnement transmis. La hauteur des arbres était significativement corrélée à la transmission du rayonnement diffus. Cependant, la valeur prédictive de ce paramètre était faible, du fait d'une très forte variance résiduelle. Les taches de soleil contribuaient à la moitié du rayonnement transmis; elles étaient à la fois intenses et de longue durée (25 min en moyenne). Au niveau de la strate herbacée, ces taches présentaient une durée plus faible (d'environ $10 \mathrm{~min}$ ). Le rayonnement transmis par le couvert de chêne représentait en moyenne $50 \%$ du rayonnement incident, et présentait une forte hétérogénéité spatiale. Le grain spatial de cette hétérogénéité était plus grossier pour le rayonnement diffus que pour le rayonnement direct, et était également plus grossier au niveau de la strate herbacée que de la strate arbustive. Ceci montre qu'un arbuste exploite cette hétérogénéité via la plasticité phénotypique, alors que dans la strate herbacée les individus ou les micropopulations entrent en compétition pour la lumière. L'abandon des pratiques traditionnelle de gestion des boisements de chêne vert conduit à une baisse simultanée de la disponibilité en lumière sous couvert et de l'hétérogénéité spatiale de ce rayonnement lumineux transmis.

photographie hémisphérique / chêne vert / rayonnement lumineux transmis sous couvert / forêts méditerranéennes / hétérogénéité spatiale

\section{INTRODUCTION}

Spatial and temporal variation of understory light has been widely accepted as an essential factor for understanding forest ecology and dynamics [9]. Quantitative measurements of understory light are crucial to understand morphological and ecophysiological adaptations to forest environments [47], and to evaluate the role of light in determining the spatial structure and dynamics of plant populations [4] and many aspects of animal behaviour $[2,52]$. Awareness of environmental heterogeneity and its consequences appeared early in the history of ecology but renewed interest on scales and patterns of heterogeneity has arisen as the consequence of the change from

\footnotetext{
*Corresponding author: valladares@ccma.csic.es
}

the simplifying assumptions of homogeneity and equilibrium of the 1960's to the incorporation of heterogeneity into theory to increase realism and predictive power $[48,53]$. Recent empirical studies have provided further support to the importance of including environmental heterogeneity in general and light heterogeneity in particular in the research of plant community processes $[4,26]$.

Spatial and temporal heterogeneity of light in forest stands is primarily influenced by the structure of the canopy since understory light is both a cause and an effect of forest dynamics $[31,33]$. Numerous studies have pointed out that high levels of species diversity can be maintained by the light heterogeneity generated via treefall gaps $[9,44]$, which suggests that a forest management enhancing spatial heterogeneity of light may lead to an enhanced biodiversity. But many uncertainties 


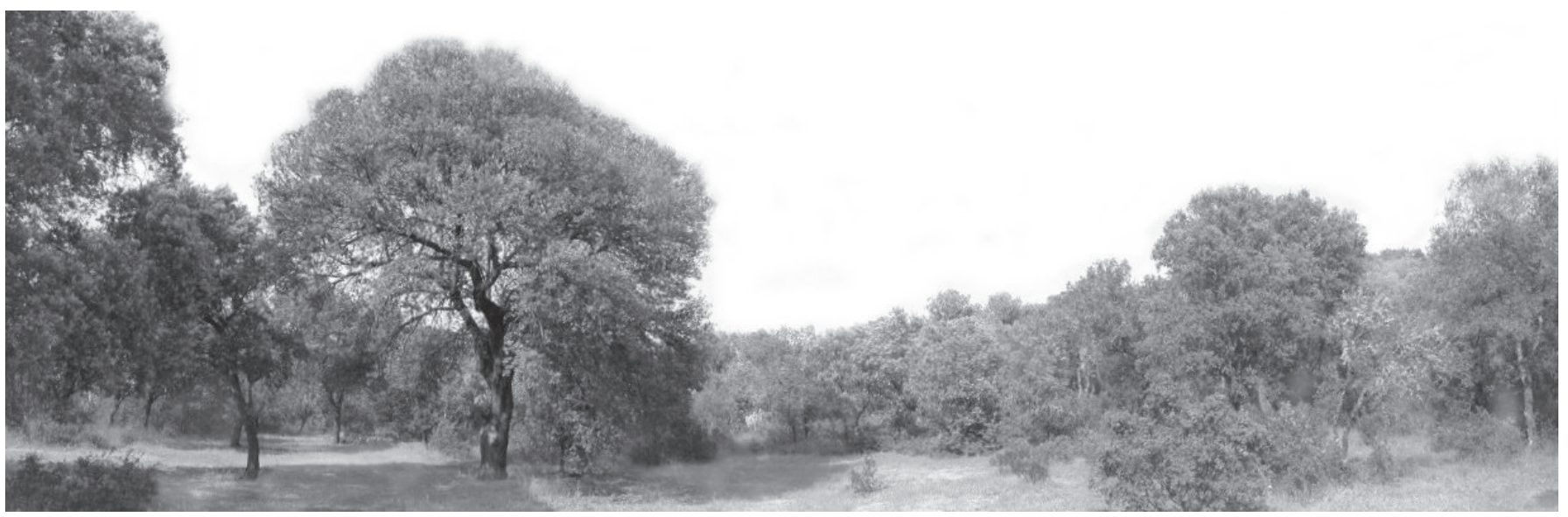

Figure 1. General view of the study site as seen from the South, showing the tree-dominated (left) and shrub-dominated (right) zones. Holm oak tree on the left is $9.5 \mathrm{~m}$ height.

to this respect still remain, particularly in forests from the Mediterranean region [48], where the number of studies describing understory light (e.g. [22]) is remarkably lower than that of moist temperate and tropical forests (e.g. [8]).

The present study explores the effect of land use change on the canopy structure and the understory light of a Holm oak woodland in central Spain. The woodland studied had two distinct zones, one where the original woodland structure dominated by a few individual Holm oak trees was still apparent, and another one dominated by shrubby Holm oaks and rockroses (Cistus ladanifer L.), which has been affected by fire in recent decades (Fig. 1). Some minor recreational activities are currently taking place in the area together with marginal livestock grazing, an increasingly common situation in the rural areas of Southern Europe. The first objective of the study was to describe mean light availability and spatial structure of light at the shrub and herb layers ( 1.2 and $0.3 \mathrm{~m}$ height respectively) in each of the two zones of this Holm oak woodland by means of hemispherical photography. By exploring the spatial autocorrelation of understory light in the two layers we wanted to unveil the scale of the heterogeneity of light and to estimate whether it affects individual plants or groups of plants. The second objective of the study was to explore the relationships between canopy features such as height, stem density or basal area, and understory light. Quantitative relationships between the structure of the canopy of a particular type of forest and its understory light open the door for the estimation of understory light at mid-to-large scales, an issue of great potential applications $[14,46]$.

\section{MATERIAL AND METHODS}

\subsection{Study area and experimental design}

The selection of the study plot was crucial because intensive measurements could only be carried out in one plot. General features of 14 Holm oak forests and woodlands of the Western Mediterranean basin were compared before selecting a zone for intensive measurements of canopy structure and understory light. This preliminary analysis revealed that canopy height decreased and basal area increased with stem density, the latter being low or medium under traditional management and high when woodlands are abandoned (results from 400-2700 sampling plots in the Spanish provinces of Madrid, Cádiz, Málaga, Huelva, Almería, Córdoba, Jaén, Sevilla and Granada - National Forestry Inventory -, and mean values reported for Gardiole de Rians, France [30], La Bruguiere, France [15], Riofrío, Segovia, Spain [45], Maremma National Park, Italy [34], La Castanya, Spain [19], and Prades, L'Avic, La Teula and B. Tornés, Spain $[21,42])$. The area between $40^{\circ} 29^{\prime}-40^{\circ} 32^{\prime} \mathrm{N}$ and $3^{\circ} 41^{\prime}$ $-3^{\circ} 47^{\prime} \mathrm{W}$ within the province of Madrid (Spain) included Holm oak formations spanning from open woodlands to closed forests with basal area, canopy height and stem density values within the range observed for these formations in the Western Mediterranean basin. Thus, the study area was found to be representative and suitable for the study. Since the goal of the study was to explore the effect of the abandonment of traditional woodland management on canopy structure and understory light we surveyed 60 zones within this area that experienced this abandonment in recent decades. Then, canopy height, used as a quick indicator of canopy structure, was measured at $6 \mathrm{~m}$ intervals in $30 \mathrm{~m}$ transects randomly established in each of these 60 zones. The final selection of the study plot resulted from the simultaneous consideration of the following criteria: (i) representative canopy structure, estimated by height, (ii) relatively flat surface to avoid moisture and nutrient gradients, (iii) existence of shrub and tree dominated patches, (iv) presence of the characteristic and dominant plant species, (v) absence of symptoms of soil degradation, pollution, erosion, (vi) no influence by roads, trails or any kind of human construction, (vii) no influence by rivers or creeks.

The study was carried out in el Monte de El Pardo (40 30' $43^{\prime \prime} \mathrm{N}$; $3^{\circ} 44^{\prime} 25^{\prime}$ W), $15 \mathrm{~km}$ to the North of the city of Madrid, Spain. Mean elevation of the zone is $640 \mathrm{~m}$ a.s.l. and it experiences a dry, continental, Mediterranean weather with a mean annual temperature of $14.8{ }^{\circ} \mathrm{C}$ and an annual precipitation of $420 \mathrm{~mm}$ for the period 1975-2001 [24]. Soils are siliceous, sandy and nutrient-poor with a slightly acidic pH. Holm oak (Quercus ilex L. subsp. ballota (Desf.) Samp.) forests and woodlands are the most extended vegetation in the area. Understory of these Holm oak woodlands and forests is poor in plant species. Woody species present in the understory or alternating with dominant trees are: Asparagus acutifolius 
L., Cistus ladanifer L., Daphne gnidium L. and Santolina rosmarinifolia $\mathrm{L}$. The ephemeral and scant herbaceous communities include species of the genera Erodium, Briza, Rumex, Aira, Agrostis, Lupinus, Brachipodium, Vulpia, Anthoxanthum, Evax, Peribalia.

In this site 900 sampling points were selected in a $30 \times 30 \mathrm{~m}$ plot at $1 \mathrm{~m}$ intervals. The selected plot presented a zone dominated by relatively large Holm oak trees and a zone dominated by shrubs (Fig. 1), which resulted in significant differences in many of the statistical analyses.

\subsection{Canopy structure and tree architecture}

Maximum canopy height, total number of stems, and stem diameter of stems $\geq 1 \mathrm{~cm}$ were measured at each of the 900 sampling quadrats. Canopy height was measured with a measuring tape when it was $\leq 2 \mathrm{~m}$; height was estimated as in Korning and Thomsen [27] for heights $>2 \mathrm{~m}$. Basal area and stem density were calculated with these data. Ten individual trees of Quercus ilex were selected at random to characterize their main architectural features by measuring stem diameter at breast height, height of the crown base and tree height, maximum diameter of the horizontal projection of the crown and its perpendicular diameter.

\subsection{Hemispherical photography and understory light variables}

Light availability at each sampling point was quantified by hemispherical photography, a widely accepted technique for exploring forest structure and understory light conditions [13,37,40]. Comparisons of methods revelead a good accuracy of hemispherical photography for the description of understory light availability particularly in heterogenous sites with a high number of gaps [5]. Photographs were taken in the center of each of the $9001-\mathrm{m}^{2}$ sampling quadrats at two heights: $1.1-1.3 \mathrm{~m}$ above the ground, corresponding to the mean height of most shrubs (referred to as shrub layer hereafter) and $0.3 \mathrm{~m}$ above the ground, corresponding to the mean height of the understory and gap herbs (referred to as herb layer hereafter). The 1800 photographs were taken using a horizontally-levelled digital camera (CoolPix 995, Nikon, Tokio, Japan), mounted on a tripod and aimed at the zenith, using a fish-eye lens of $180^{\circ}$ field of view (FCE8, Nikon). Digital photography has been shown to render even better results than traditional methods using films and analog technologies [17]. Photographs were analysed for canopy openness using Hemiview canopy analysis software version 2.1 (1999, Delta-T Devices Ltd, United Kingdom). This software is based on the program CANOPY $[37,38]$. Photographs were taken under homogenous sky conditions to minimize variations due to exposure and contrast, and they were analysed by a single person following always the same protocol for classifying and tresholding. Two estimates of errors (taking five photographs ten different times and processing the same five photographs ten different times during the analysis) revealed a noise of $4-5 \%$ and an adequate repetitivity of the results.

The direct site factor (DSF) and the indirect site factor (ISF) were computed by Hemiview accounting for the geographical location of the site. These factors are estimates of the fraction of direct, and diffuse or indirect radiation, respectively, expected to reach the spot where the photograph was taken [1]. The hemispheric distribution of irradiance used for calculations of diffuse radiation was standard overcast sky conditions. A total of 160 sky sectors were considered resulting from 8 azimuth times 20 zenith divisions. Other variables estimated from each photograph with Hemiview were effective leaf area index $(\mathrm{LAI}$ eff $)$, ground cover and visible sky. Values of $\mathrm{LAI}_{\mathrm{eff}}$ were found by Hemiview, which produces the best fit to the actual gap fractions measured from the hemispherical photograph. Calculation of $\mathrm{LAI}_{\text {eff }}$ by Hemiview involves use of Beer's Law, which can be expressed as follows:

$$
\mathrm{G}(\theta)=\exp \left(-\mathrm{K}(\theta) \mathrm{LAI}_{\mathrm{eff}}\right)
$$

where $G$ is gap fraction, and $K(\theta)$ is the extinction coefficient at zenith angle $\theta$. $\mathrm{LAI}_{\mathrm{eff}}$ estimated by the inversion process may not be an exact measure of the LAI of the real canopy. Indirect calculations of LAI, such as those conducted by Hemiview, assume a random distribution of canopy elements, such that gap fraction should be observed for a small enough annulus that randomness can be assumed. LAI calculated in this manner is termed effective $\mathrm{LAI}\left(\mathrm{LAI}_{\text {eff }}\right)$, since it does not account for non-random distribution of foliage and includes the sky obstruction by branches and stems. Effective leaf area index $\left(\mathrm{LAI}_{\text {eff }}\right)$ was estimated as half of the total leaf area per unit ground surface area [12], based on an ellipsoidal leaf angle distribution [7].

Ground cover (GndCover) was defined as the vertically projected canopy area per unit ground area. It gives the proportion of ground covered by canopy elements as seen from a great height, and is calculated assuming the canopy displays an ellipsoidal distribution

$$
\text { GndCover }=1-\exp (-\mathrm{K}(\mathrm{x}, 0) \mathrm{LAI})
$$

where $K(x, 0)$ is the extinction coefficient for a zenith angle of zero, $\mathrm{x}$ is the ellipsoidal leaf angle distribution. VisSky is an overall proportion of the sky hemisphere that is visible, which is calculated as follows:

$$
\text { VisSky }=\Sigma \text { VisSky } \theta, \alpha
$$

where VisSky $\theta, \alpha$ is the proportion of visible sky in a given sky sector with zenith angle $\theta$, and compass angle $\alpha$ relative to the entire hemisphere of sky directions.

Hemispherical photographs were also used for the estimation of sunflecks (i.e. quick and significant increases of photosynthetically active radiation due to at least some direct sunlight added to the low intensity background understory diffuse light) near the spring and autumn equinoxes, more precisely for the 10th of April and October, the latter within the period of data collection in the field. Number of sunflecks per day and their mean duration were registered, and the percentage of total radiation received as sunflecks was calculated as

$\% \mathrm{PPFD}$ received as sunflecks $=100 \Sigma \mathrm{Q}_{\text {int,sunflecks }} / \mathrm{GSF}_{\mathrm{int}, \text { open }}$

where $\mathrm{Q}_{\text {int,sunflecks }}$ is the total integrated photosynthetic photon flux density (PPFD) received by a given sunfleck, GSF is the global site factor as calculated by Hemiview for a clear day (GSF $=0.9 \mathrm{DSF}+$ 0.1ISF), and $\mathrm{Q}_{\text {int,open }}$ is the total daily PPFD in the open for a clear day. The value for $\mathrm{Q}_{\text {int,open }}$ was obtained from the meteorological information available for the nearby city of Madrid: the mean for the period 1975-2001 for October 10th was $32 \mathrm{~mol} \mathrm{~m}^{-2}$ day $^{-1}$ [24]. Diffuse light was assumed to contribute with $10 \%$ of the total radiation for the calculation of GSF, which is a good estimate for clear days under a range of atmospheric conditions [39].

\subsection{Spatial heterogeneity analyses and statistics}

Spatial heterogeneity in three canopy architecture and six hemispherical photography variables was explored in the two forest layers 
and in the two zones of the plot by means of variograms, correlograms and interpolated maps using the software GS+ 5.0 (Gamma Design Software, Plainville, Michigan, USA). Spatial autocorrelation, or distance dependency, was modeled by fitting a semivariogram function to an empirically obtained semivariogram. This empirical semivariogram was obtained by plotting half of the squared difference between two observations (the semivariance) against their distance in space, averaged for a series of distance classes [25, 29]. A simple semivariogram model is defined by the parameters sill (the average half squared difference of two independent observations), nugget (the variance within the sampling unit, in our case the $1-\mathrm{m}^{2}$ quadrats), and range (the maximum distance at which pairs of observations will influence each other, taken here as the distance at which the function has reached $95 \%$ of the difference between sill and nugget) [51]. Spatial structure for a given variable can be estimated by (sill-nugget)/sill, which reflects the spatially dependent predictability of the property [18]. In our study, best fit of the semivariogram function was obtained with a lag class distance, which defines how pairs of points will be grouped into lag classes, of $1.28 \mathrm{~m}$. The active lag distance (i.e. the distance over which semivariance is calculated) was set as $70 \%$ of the maximum lag distance $(42 \mathrm{~m})$ between two sampling points in the study to eliminate border effects and discard values with a low number of pairs of data points. Spatial autocorrelation was quantified by Moran's $I$ coefficient $[29,32]$. This analysis produces a correlogram, a spatial structure function describing the change in autocorrelation with increasing distance between sampling points. Moran's $I$ coefficient generally varies from -1.0 indicating negative correlation, to +1.0 indicating positive correlation between means that are a given distance apart. Significance of the Moran's $I$ coefficient was calculated with Moran.exe (Richard Duncan 1990, for more details see [16]).

Semivariograms calculated by GS + were modeled with authorized (e.g. spherical, exponential, Gaussian) isotropic models, and were used to produce continuous maps based on real data and predictions for unsampled locations using ordinary kriging [25]. In our case, interpolation was done using a uniform grid, by block-kriging with a local grid of $2 \times 2$.

Two-way ANOVA was used to test for significant differences in the target variables between the two forest layers and the two zones of the plot. Pearson correlation coefficients and their significance were used to analyze the relationships between canopy architecture and hemispherical photography variables. In order to explore whether the sampling points to the South of the target point influenced the estimations of the hemispherical photography variables, correlations between canopy architecture variables obtained in each $1-\mathrm{m}^{2}$ sampling point and the mean values of this point and the three points to South for the hemispherical photography variables were also calculated. Linear regression analysis was applied for the highest and most significant correlations to obtain potential estimations of understory light (ISF and DSF) from canopy architecture parameters. All statistical analyses were performed using STATISTICA 5.0 (Statsoft, Incorporated, Tulsa, Oklahoma, USA).

\section{RESULTS}

\subsection{Canopy structure and understory light in two strata and two zones}

The Holm oak woodland studied was on average short (mean height of $2.4 \mathrm{~m}$, mean height of individual Holm
Table I. Mean and standard deviation (SD) of canopy height, number of stems and basal area for the $9001-\mathrm{m}^{2}$ sampling points of the study plot, and mean and standard deviation of the height, projected area, thickness and volume of the crown of ten randomly chosen individual trees of Holm oak (Quercus ilex subsp. ballota).

\begin{tabular}{lll}
\hline & Mean & SD \\
\hline Canopy height $(\mathrm{m})$ & 2.4 & 1.7 \\
Number of stems $\left(\mathrm{m}^{-2}\right)$ & 1.4 & 2.3 \\
Basal area $\left(\mathrm{m}^{2} \mathrm{ha}^{-1}\right)$ & 14.5 & 158.7 \\
Quercus ilex subsp. ballota & & \\
$\bullet$ Crown height $(\mathrm{m})$ & 5.5 & 1.6 \\
$\bullet$ Projected crown $\left(\mathrm{m}^{2}\right)$ & 17.7 & 31.4 \\
$\bullet$ Crown length $(\mathrm{m})$ & 3.3 & 1.9 \\
$\bullet$ Crown volume $\left(\mathrm{m}^{3}\right)$ & 96.5 & 217.6 \\
\hline
\end{tabular}

Table II. Mean and standard deviation (SD) of eight hemispherical photography variables (visible sky, ground cover, effective leaf area index $-\mathrm{LAI}_{\mathrm{eff}}{ }^{-}$, indirect and direct site factors, number and duration of sunflecks and percentage of radiation received as sunflecks) calculated for the two layers across the entire Holm Oak plot studied.

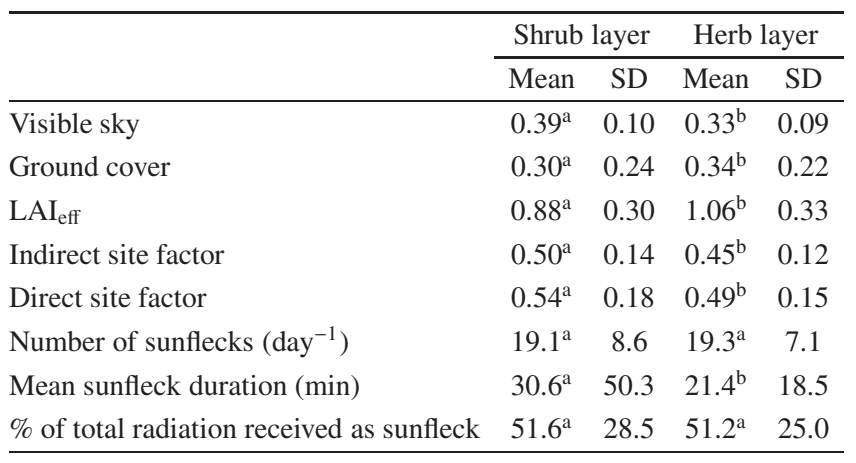

Letter code indicate significant differences (ANOVA, $p<0.05$ ) between the two forest layers.

oak trees of $5.5 \mathrm{~m}$, Tab. I) and stem density was high: 14500 stems ha $^{-1}$, of which only 989 displayed a d.b.h. above $5 \mathrm{~cm}$. Stem density was relatively high, canopy height low and basal area intermediate in comparison with other European Holm oak forests. Only three shrub species had stems larger than $1 \mathrm{~cm}$ : 3989 stems ha $^{-1}$ of Cistus ladanifer (basal area of $1.2 \mathrm{~m}^{2} \mathrm{ha}^{-1}$ ), 222 stems ha ${ }^{-1}$ of Daphne gnidium, and 200 stems ha $^{-1}$ of Santolina rosmarinifolia. Mean cover of the plot was $32 \%$ and mean effective leaf area index $\left(\mathrm{LAI}_{\text {eff }}\right)$ was $1.1 \mathrm{~m}^{2} \mathrm{~m}^{-2}$

Mean radiation in the understory of the plot was ca. $50 \%$ of that available in the open for both direct (DSF) and indirect radiation (ISF, Tab. II). Both canopy structure and available radiation differed between herb $(30 \mathrm{~cm})$ and shrub layers $(1.1-$ $1.3 \mathrm{~m}$ ). Cover and $\mathrm{LAI}_{\mathrm{eff}}$ were significantly different between the layers, being higher in the herb than in the shrub layer, while the reverse was true for most of the understory light parameters (Tab. II). Canopy structure and understory light were also different in the tree-dominated vs. the shrub-dominated zone, besides height, which was the criterion for differentiat- 




Figure 2. Map of the canopy height $(\mathrm{m})$ of the studied Holm oak woodland. The map was based on 900 sampling points interpolated by Krigging using the exponential model for the semivariogram $\left(r^{2}=0.86\right)$. The two zones of the plot (tree- and shrub-dominated zones) are indicated on the map. Distances shown in the axes are in $\mathrm{m}$.

ing the two zones. Basal area was higher in the tree- than in the shrub-dominated zone, while stem density was higher in the shrub-dominated zone (Fig. 2, Tab. III). Cover and LAI $\mathrm{eff}$ were higher in the tree-dominated zone but only at the shrub layer, since the trend was reversed at the herb layer (Tab. III). As a consequence of this, both ISF and DSF were lower in the tree-dominated han in the shrub-dominated zone at the shrub layer, while the reverse was true at the herb layer.

Sunflecks estimated for a clear day near the equinox contributed half of the total daily radiation available in the understory and were rather long (25 min). The number of sunflecks and their relative contribution to the total understory radiation was similar in the two layers, but sunflecks were on average 10 min shorter at the herb layer (Tab. II). Sunflecks were more abundant in the tree-dominated zone but only at the shrub layer since no differences were found at the herb layer. The contribution of these sunflecks to the total daily radiation of the understory was lower in the shrub-dominated zone than in the tree-dominated zone but only at the herb layers (Tab. III).

\subsection{Relationships between canopy structure and hemispherical photography variables}

Correlation between canopy structure and understory light was enhanced by considering the two zones (tree- and shrub dominated) separately, particularly in the case of basal area. Canopy height was the canopy structural variable that exhibited the most significant correlation with understory light and with other variables estimated with hemispherical photography. The highest correlation was obtained for height and cover.
Correlations between height and hemispherical photography variables were higher at shrub than at herb layer, while the reverse was true for the stem density (Tab. IV). Correlation between height and understory light was higher in the tree-zone where the height range was higher. Even though all regressions between height and understory light were significant, the fraction of variance explained by height was modest and different in each case. The most robust regressions $\left(r^{2}>0.3\right)$ were found for indirect light, being always higher in the treedominated than in the shrub dominated zone, and at the shrub than at herb layer (Tab. V). The usage of $4 \mathrm{~m}^{2}$ sampling points instead of $1 \mathrm{~m}^{2}$ for the canopy structural variables by including the three sampling points to the South of a given point improved the correlations in all cases, particularly the correlation between height and direct light (DSF, Tab. V).

\subsection{Spatial heterogeneity of the canopy and the understory light in two strata and two zones}

Most variables exhibited a good fit ( $r^{2}$ from 0.63 to 0.99 ) to the theoretical semivariogram models, which indicated that a general and significant spatial structure of the variables studied was captured by the $1 \mathrm{~m}^{2}$ grid used. Autocorrelation at $1 \mathrm{~m}$ lags was high and significant for all variables except for basal area. Significant differences in the spatial structure were found between the two layers of the woodland, with better fit to the models at shrub than at herb layer (Tab. VI, Figs. 3 and 4). Semivariance and autocorrelation values for range distances larger than $20 \mathrm{~m}$ can be influenced by border effects and 
Table III. Mean and standard deviation (SD) of canopy height, number of stems, basal area and eight hemispherical photography variables (visible sky, ground cover, effective leaf area index $-\mathrm{LAI}_{\mathrm{eff}}{ }^{-}$, indirect and direct site factors, number and duration of sunflecks and percentage of radiation received as sunflecks) calculated for the two layers of the Holm Oak forest. Values for the two zones (tree- and shrub-dominated zones) are given separately.

\begin{tabular}{|c|c|c|c|c|}
\hline & \multicolumn{2}{|c|}{ Tree-dominated zone } & \multicolumn{2}{|c|}{ Shrub-dominated zone } \\
\hline & Mean & SD & Mean & SD \\
\hline Height (m) & $3.57^{\mathrm{a}}$ & 2.90 & $2.04^{\mathrm{b}}$ & 1.57 \\
\hline Number of stems $\left(\mathrm{m}^{-2}\right)$ & $0.71^{\mathrm{a}}$ & 2.18 & $1.65^{\mathrm{b}}$ & 2.33 \\
\hline Basal area $\left(\mathrm{m}^{2} \mathrm{ha}^{-1}\right)$ & $25.1^{\mathrm{a}}$ & 32.1 & $11.3^{\mathrm{b}}$ & 38.2 \\
\hline \multicolumn{5}{|l|}{ Shrub Layer } \\
\hline VisSky & $0.37^{\mathrm{a}}$ & 0.09 & $0.39^{\mathrm{a}}$ & 0.10 \\
\hline GndCover & $0.34^{\mathrm{a}}$ & 0.24 & $0.29^{\mathrm{b}}$ & 0.24 \\
\hline $\mathrm{LAI}_{\mathrm{eff}}$ & $0.90^{\mathrm{a}}$ & 0.27 & $0.88^{\mathrm{a}}$ & 0.30 \\
\hline ISF & $0.48^{\mathrm{a}}$ & 0.14 & $0.51^{\mathrm{b}}$ & 0.14 \\
\hline DSF & $0.49^{\mathrm{a}}$ & 0.18 & $0.55^{\mathrm{b}}$ & 0.17 \\
\hline Number of sunflecks & $22.0^{\mathrm{a}}$ & 9.5 & $18.0^{\mathrm{b}}$ & 8.2 \\
\hline Sunfleck duration & $23.0^{\mathrm{a}}$ & 29.0 & $33.0^{\mathrm{b}}$ & 55.0 \\
\hline$\%$ of total radiation received as sunfleck & $52.2^{\mathrm{a}}$ & 27.0 & $49.6^{\mathrm{a}}$ & 33.0 \\
\hline \multicolumn{5}{|l|}{ Herb Layer } \\
\hline VisSky & $0.40^{\mathrm{a}}$ & 0.07 & $0.31^{\mathrm{b}}$ & 0.08 \\
\hline GndCover & $0.30^{\mathrm{a}}$ & 0.20 & $0.35^{\mathrm{b}}$ & 0.23 \\
\hline $\mathrm{LAI}_{\mathrm{eff}}$ & $0.80^{\mathrm{a}}$ & 0.21 & $1.13^{\mathrm{b}}$ & 0.32 \\
\hline ISF & $0.52^{\mathrm{a}}$ & 0.11 & $0.42^{\mathrm{b}}$ & 0.11 \\
\hline DSF & $0.55^{\mathrm{a}}$ & 0.15 & $0.46^{\mathrm{b}}$ & 0.14 \\
\hline Number of sunflecks & $20.0^{\mathrm{a}}$ & 7.7 & $19.2^{\mathrm{a}}$ & 0.9 \\
\hline Sunfleck duration & $26.7^{\mathrm{a}}$ & 27.8 & $19.8^{\mathrm{b}}$ & 14.1 \\
\hline$\%$ of total radiation received as sunfleck & $54.4^{\mathrm{a}}$ & 25.1 & $40.7^{\mathrm{b}}$ & 21.8 \\
\hline
\end{tabular}

Letter code indicate significant differences (ANOVA, $p<0.05$ ) between the two forest zones.

thus should be taken as tentative. The shrub layer exhibited greater spatial structure than the herb layer for most variables, particularly for those related with understory light (Tab. VI, Fig. 4). Spatial heterogeneity of light had a coarser grain for indirect (ISF) than for direct light (DSF), which was revealed by a longer range for ISF than for DSF (19.8 vs. $10.2 \mathrm{~m}$ respectively) and a higher autocorrelation at $4.5 \mathrm{~m}$ (0.2 vs. 0.1 respectively, Tab. VI). The range of the semivariogram was 4 $7 \mathrm{~m}$ for variables with $r^{2}>0.9$ at the shrub layer while it was notably larger at the herb layer, even larger than the size of the plot for variables like canopy height or basal area (Tab. VI). Autocorrelation was higher in general at the herb than at the shrub layer, and while all variables exhibited a low $(0.1-0.3)$ but significant autocorrelation at $4.5 \mathrm{~m}$ at the herb layer, only $\mathrm{LAI}_{\text {eff }}$ and ISF exhibited a significant autocorrelation at $4.5 \mathrm{~m}$ at the shrub layer.

The geostatistical study of the plot for each of the two zones separately rendered improved fits of the semivariogram models and a higher spatial structure of the variables than the study of the plot as a whole (Tabs. VI and VII). This was particularly clear in variables like the duration of sunflecks. The tree-dominated zone had a greater spatial structure and a higher autocorrelation than the shrub-dominated zone (Tab. VII, Fig. 4). The range of the semivariogram was shorter in the tree-dominated zone, especially in the case of understory light variables.

\section{DISCUSSION}

\subsection{Understory light of Holm oak woodlands}

Management and water availability are the two most important determinants of mean light availability in the understory of Mediterranean forests, but current understanding of their precise influence on understory light is very poor $[41,43,48]$. From the few studies in Mediterranean ecosystems, it can be concluded that the understory of mature forests when water limitations are not severe can be as dark as that of other temperate or tropical forests, with understory photosynthetic photon flux density (PFD) ranging from 2 to $7 \%$ in Spanish and Italian old growth Holm oak forests having leaf area indexes (LAI) around $4 \mathrm{~m}^{2} \mathrm{~m}^{-2}[20,22]$. The understory of the Holm oak forest studied here was about one order of magnitude brighter than that from those old growth forests, with a mean $50 \%$ of transmitted PFD (Tabs. II and III), due at least in part to a lower LAI (LAI $\mathrm{eff}_{\mathrm{f}}$ ca. $1 \mathrm{~m}^{2} \mathrm{~m}^{-2}$ ). The Holm oak formation studied here was not a mature, old growth forest, but a relatively short and open woodland with scattered individual trees intermixed with shrubs. This is a very common kind of 


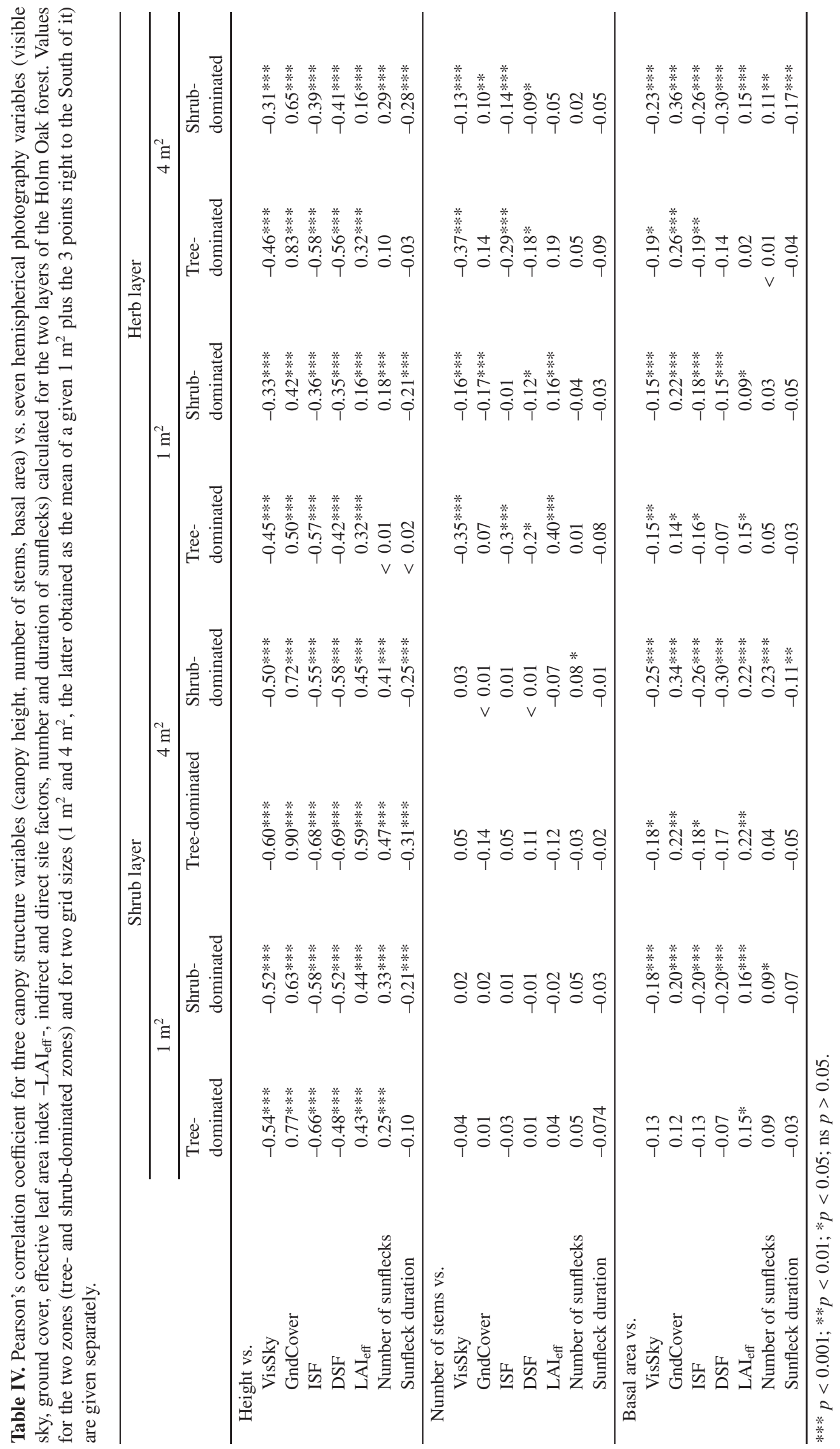




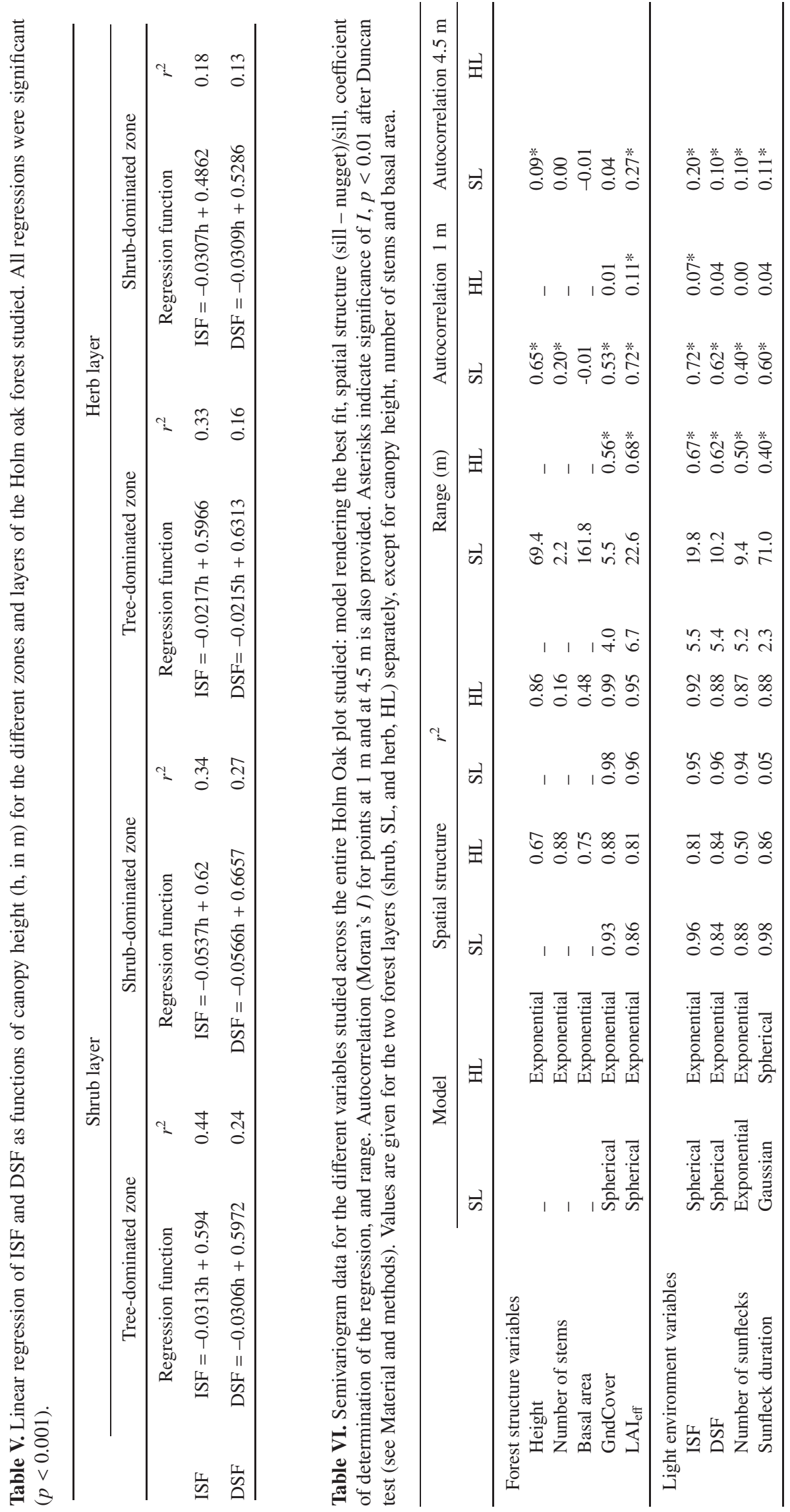




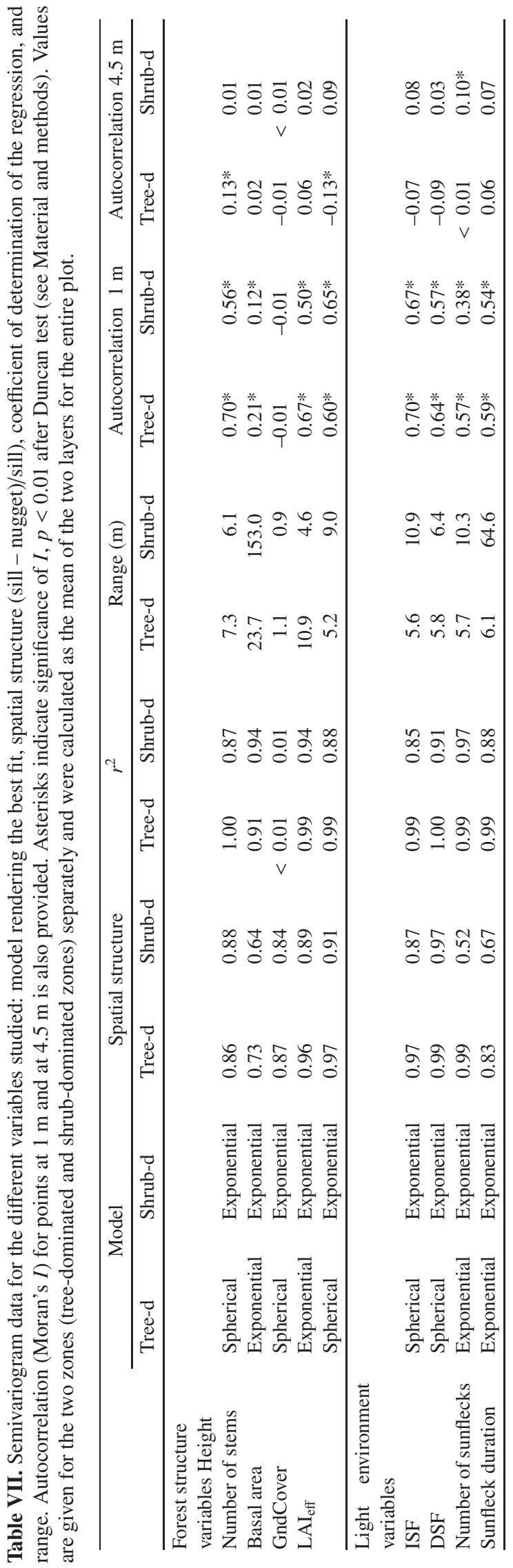



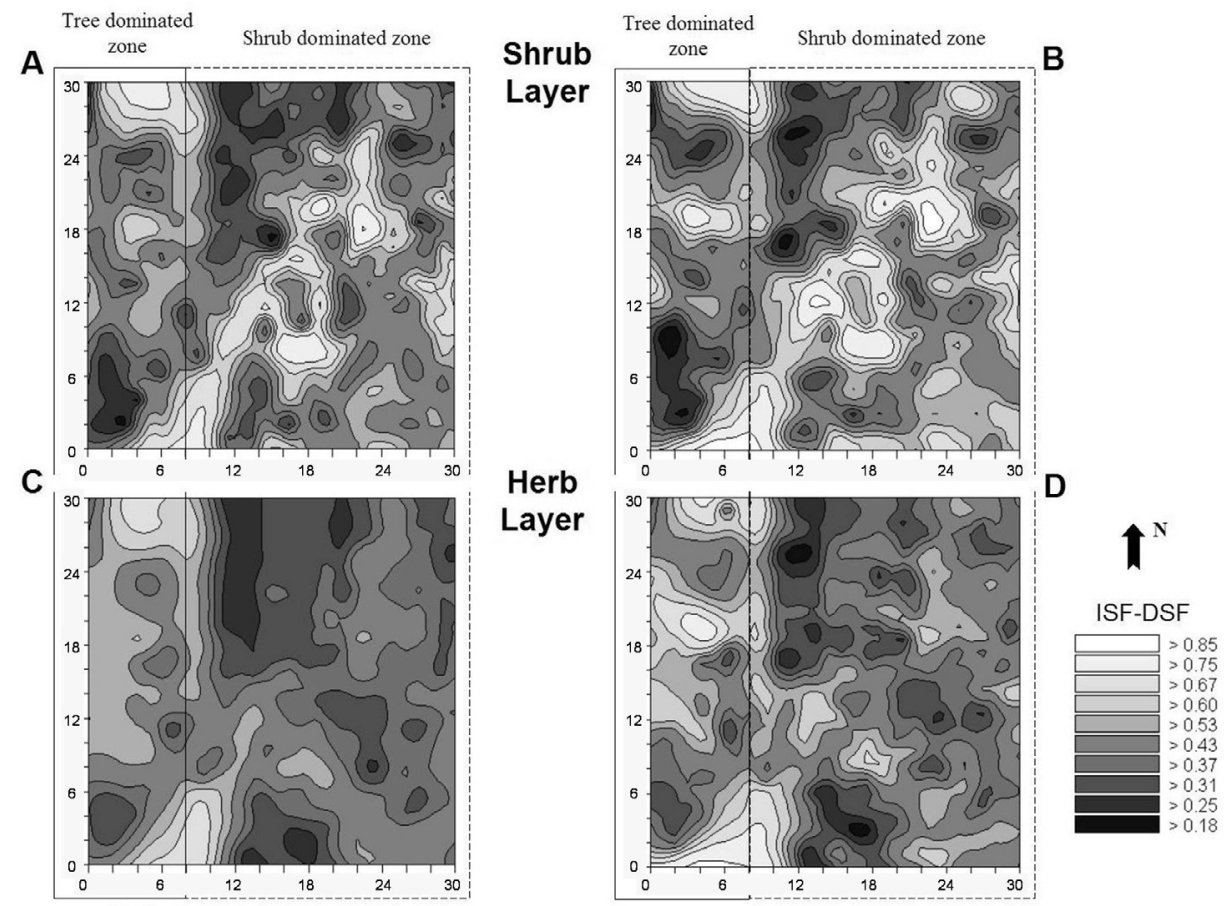

Figure 3. Map of the understory radiation for the Holm oak woodland studied. Maps represent indirect site factor (ISF, A and C) and direct site factor (DSF, B and D) for either the shrub layer (A and B) or the herb layer (C and D). The map was based on 900 sampling points interpolated by Krigging using spherical and exponential models for the semivariogram (see details and $r^{2}$ in Tab. VI). The two zones of the plot (tree- and shrub-dominated zones) are indicated on the map. Distances shown in the axes are in $\mathrm{m}$.

vegetation in many current Mediterranean ecosystems, where abandoned woodlands and shrublands develop in the absence of too frequent or intense perturbations towards still not welldefined Holm oak forests [6].

Another distinctive feature of the understory light of the studied Holm oak woodland was the long duration and high intensity of sunflecks (Tab. II). Even though the fraction of understory light provided by sunflecks (ca. 50\%) was only slightly lower than that for other temperate and tropical old growth forests, their physiological implications could be very different. Understory light in those old growth forests is very scant $(<10 \%$ and even $<5 \%[4,8,53])$, and sunflecks are short and of moderate intensity so they are used in photosynthesis very efficiently $[35,49]$, positively influencing survival and performance of understory plants $[10,36]$. But sunflecks in the understory of the studied Holm oak forest were very intense, approaching full sunlight intensity in the open, and very long (20-30 min vs. few s in mature, old growth forests [11]). These two features make the photosynthetic exploitation of sunflecks by understory plants very inefficient. In fact, long and intense sunflecks can lead to severe photoinhibition, since the extent of photoinhibition is proportional to the light dose [50].

The different spatial scales of light heterogeneity at each of the two layers studied, with a range of the semivariogram of $5 \mathrm{~m}$ for the shrub layer and of 10-20 $\mathrm{m}$ for the herb layer, could have important functional implications. The fine-grained light heterogeneity at the shrub layer together with the large size of individual plants indicates that this heterogeneity is mainly exploited by different leaves of a given individual by means of phenotypic plasticity. In contrast, the coarse-grained light heterogeneity at the herb layer together with the small size of individual plants indicates that this heterogeneity is exploited by different micropopulations. Our study reveals that abandonment of traditional management of Holm oak woodlands and the corresponding increase of shrub cover leads to a decrease in both the availability and the spatial heterogeneity of understory light, but more research efforts are needed to understand causes and consequences of changes in understory light in Mediterranean forests if we are to predict and mitigate the effects of global change on the regeneration and dynamics of these forests.

\subsection{Canopy structure and light interception: potentials for indirect estimates of understory light}

Quick and easy estimates of understory light are of great potential for forest management since light determines many functional processes and it is directly affected by most silvicultural practices $[3,23,46]$. Since canopy structural features determine light penetration, understory light can be estimated by quantifying some of these features and both theoretical and 

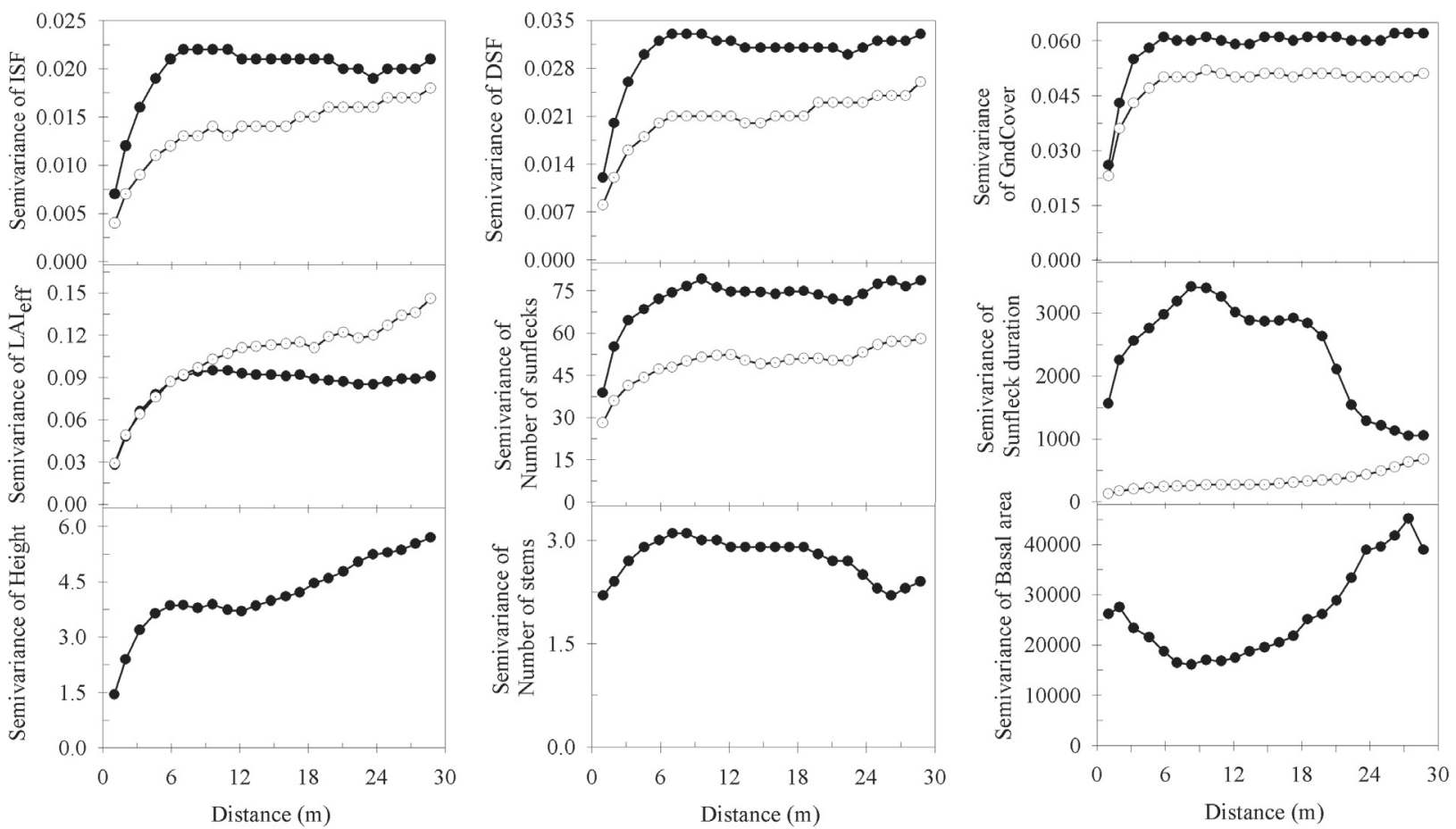

Figure 4. Semivariograms for nine variables studied (see Tab. VI for more details). Values for the shrub (closed symbols) and herb (open symbols) layers are given separately. Note that for the structural variables canopy height, number of stems and basal area no distinction between layers was made and only one symbol is used.

empirical studies have been carried out in this direction for more than four decades [1]. However, previous studies in tropical forests have revealed a poor agreement between architecture of dominant trees and understory light [5,31]. In our case, despite the significant correlation of direct and indirect light with vegetation height (Tab. VI), the regression models examined were not very robust. Although the forest canopy studied here is rather simple, only indirect radiation (ISF) could be reasonably well estimated as a linear function of canopy height, although only in the tree-dominated zone of the plot (Tab. V). The value of canopy height as an estimator of understory light in forests similar to the one studied here relies on the simplicity of its determination but not on the accuracy of the estimations of understory light that can be obtained. The incorporation of other canopy features (e.g. leaf angle distribution, leaf and branch clustering) is likely to increase significantly the accuracy of the estimation of understory light based on canopy structure, but the advantages of this regression approach when compared with hemispherical photography itself are likely to vanish due to the large efforts needed to determine these features. Other variables such as basal area could also be used for the estimation of understory light, but pilot studies are needed to determine the best protocol and sampling scale and density.

The inclusion of the three neighbor points situated immediately to the South of the target point significantly increased the correlation of vegetation height and understory light (particularly direct light, DSF), suggesting that pilot studies are necessary to adjust the size and relative position of the area to be sampled in each case. The size of this area and the agreement between structural variables and understory light is specific for each forest due to the varying influence of canopy height and complexity, and latitude as shown elsewhere [14,28,31].

Acknowledgements: Special thanks are due to Libertad Gonzalez, Daniela Brites, Silvia Matesanz, David Tena and David Sanchez for support, to Itziar Rodriguez and Miguel Angel Zavala for facilitating access to Holm oak data from the Spanish Forestry inventory, and to Rebecca Montgomery for a critical revision of the manuscript. Financial support was provided by two grants of the Spanish Ministry for Science and Technology (RASINV, CGL2004-04884-C02-02/BOS, and PLASTOFOR, AGL2004-00536/FOR). BGA was supported by a CSIC Introduction to Science fellowship.

\section{REFERENCES}

[1] Anderson M.C., Stand structure and light penetration. II. A theoretical analysis, J. Appl. Ecol. 3 (1966) 41-54.

[2] Barbosa P., Wagner M.R., Introduction to forest and shade tree insects, Academic Press, San Diego, 1989.

[3] Barnes B.B., Zak D.R., Denton S.R., Spurr S.H., Forest ecology, John Wiley and Sons Inc., New York, 1998. 
[4] Beckage B., Clark J.S., Seedling survival and growth of three forest tree species: the role of spatial heterogeneity, Ecol. 84 (2003) 18491861 .

[5] Bellow J.G., Nair P.K.R., Comparing common methods for assessing understory light availability in shaded-perennial agroforestry systems, Agric. For. Meteorol. 114 (2003) 197-211.

[6] Blondel J., Aronson J., Biology and wildlife of the Mediterranean region, Oxford University Press, New York, 1999

[7] Campbell G.S., Extinction coefficients for radiation in plant canopies calculated using an ellipsoidal inclination angle distribution, Agric. For. Meteorol. 36 (1986) 317-321.

[8] Canham C.D., Denslow J.S., Platt W.J., Runkle J.R., Spies T.A., White P.S., Light regimes beneath closed canopies and tree-fall gaps in temperate and tropical forests, Can. J. For. Res. 20 (1990) 620 631 .

[9] Canham C.D., Finzi A.C., Pacala S.W., Burbank D.H., Causes and consequences of resource heterogeneity in forests - interspecific variation in light transmission by canopy trees, Can. J. For. Res. 24 (1994) 337-349.

[10] Chazdon R.L., Sunflecks and their importance to forest understory plants, Adv. Ecol. Res. 18 (1988) 1-63.

[11] Chazdon R.L., Pearcy R.W., The importance of sunflecks for forest understory plants, BioSci. 41 (1991) 760-766.

[12] Chen J.M., Black T.A., Defining leaf area index for non-flat leaves, Plant Cell Environ. 15 (1992) 421-429.

[13] Chen J.M., Black T.A., Adams R.S., Evaluation of hemispherical photography for determining plant area index and geometry of a forest stand, Agric. For. Meteorol. 56 (1991) 129-143.

[14] Clark D.B., Clark D.A., Rich P.M., Weiss S.B., Oberbauer S.F., Landscape-scale evaluation of understory light and canopy structure: methods and application in a neotropical lowland rain forest, Can. J. For. Res. 26 (1996) 747-757

[15] Ducrey M., Sylviculture des taillis de chêne vert. Pratiques traditionnelles et problématique des recherches récentes, Rev. For. Fr. 40 (1988) 302-313.

[16] Duncan R.P., Flood disturbance and the coexistence of species in a lowland podocarp forest, south Westland, New Zealand, J. Ecol. 81 (1993) 403-416.

[17] Englund S.R., O’Brien J.J., Clark D.B., Evaluation of digital and film hemispherical photography and spherical densiometry for measuring forest light environments, Can. J. For. Res. 30 (2000) 19992005 .

[18] Ettema C.H., Wardle D.A., Spatial soil ecology, Trends Ecol. Evol. 17 (2002) 177-183.

[19] Ferres L., Biomasa, producción y mineralomasa del encinar de La Castanya (Montseny), Ph.D. dissertation, Universidad Autónoma de Barcelona, Spain, 1984

[20] Gracia C., Response of the evergreen oak to the incident radiation at the Montseny (Barcelona, Spain), Bull. Soc. Bot. Fr. 131 (1984) 595-597.

[21] Gracia C., Bellot J., Baeza J., Tello E., Sabate S., Roda F., A longterm thinning experiment on a Quercus ilex L. forest: Main working hypotheses and experimental design, in: International symposium on experimental manipulations of biota and biogeochemical cycling in ecosystems: approach, methodologies, findings, Copenhagen, Denmark, 1992

[22] Gratani L., Canopy structure, vertical radiation profile and photosynthetic function in a Quercus ilex evergreen forest, Photosynthetica 33 (1997) 139-149.
[23] Horn H.S., The adaptive geometry of trees, Princeton University Press, Princeton, New Jersey, 1971.

[24] Instituto-Nacional-de-Meteorología, Calendario meteorológico 2003, Ministerio de Medio Ambiente, Madrid, 2003.

[25] Isaaks E.H., Srivastava R.M., An introduction to applied geostatistics, Oxford University Press, New York, 1989.

[26] Jurena P.N., Archer S., Woody plant establishment and spatial heterogeneity in grasslands, Ecology 84 (2003) 907-919.

[27] Korning J., Thomsen K., A new method for measuring tree height in tropical rain forest, J. Veg. Sci. 5 (1994) 139-140.

[28] Kuuluvainen T., Tree architectures adapted to efficient light utilization: is there a basis for latitudinal gradients? Oikos 65 (1992) 275284.

[29] Legendre P., Forin M.J., Spatial pattern and ecological analysis, Vegetatio, 80 (1989) 107-138.

[30] Miglioretti F., Contribution à l'étude de la production des taillis de chêne vert en forêt de la Gardiole de Rians (Var), Ann. Sci. For. 44 (1987) 227-242.

[31] Montgomery R.A., Chazdon R., Forest structure, canopy architecture, and light transmittance in tropical wet forests, Ecology 82 (2001) 2707-2718.

[32] Moran P.A.P., Notes on continuous stochastic phenomena, Biometrika 37 (1950) 17-23.

[33] Nicotra A.B., Chazdon R.L., Iriarte S.V.B., Spatial heterogeneity of light and woody seedling regeneration in tropical wet forests, Ecology 80 (1999) 1908-1926.

[34] Nocentini S., Piusii P., Osservazioni priliminari sulla macchia del Parco della Maremma, Inf. Bot. ital. 9 (1977) 174-184.

[35] Pearcy R.W., Sunflecks and photosynthesis in plant canopies, Ann. Rev. Plant Physiol. Plant Mol. Biol. 41 (1990) 421-453.

[36] Pearcy R.W., Pfitsch W.A., The consequences of sunflecks for photosynthesis and growth of forest understory plants, in: Schulze E.-D., Caldwell M.M. (Eds.), Ecophysiology of Photosynthesis, Springer-Verlag, Heidelberg, 1994, pp. 343-359.

[37] Rich P.M., Characterizing plant canopies with hemispherical photographs, Remote Sens. Rev. 5 (1990) 13-29.

[38] Rich P.M., Clark D.B., Clark D.A., Oberbauer S.F., Long-term study of solar radiation regimes in a tropical wet forest using quantum sensors and hemispherical photography, Agric. For. Meteorol. 65 (1993) 107-127.

[39] Ross J., Sulev M., Sources of errors in measurements of PAR, Agric For. Meteorol. 100 (2000) 103.

[40] Roxburgh J.R., Kelly D., Uses and limitations of hemispherical photography for estimating forest light environments, N. Z. J. Ecol. 19 (1995) 213-217.

[41] Sabaté S., Sala A., Gracia C.A., Leaf traits and canopy organization, in: Rodá F. et al. (Eds.), Ecology of Mediterranean evergreen oak forests, Springer Verlag, Berlin, 1999, pp. 121-134.

[42] Sala A., Tenhunen J.D., Site-specific water relations and stomatal response of Quercus ilex L. in a Mediterranean watershed, Tree Physiol. 14 (1994) 601-617.

[43] Scarascia-Mugnozza G., Oswald H., Piussi P., Radoglou K., Forests of the Mediterranean region: gaps in knowledge and research needs, For. Ecol. Manage. 132 (2000) 97-109.

[44] Schnitzer S.A., Carson W.P., Treefall gaps and the maintenance of species diversity in a tropical forest, Ecology 82 (2001) 913-919. 
[45] Serrada-Hierro R., Bravo-Fernández J.A., Roig-Gómez S., Brotación en encinas (Quercus ilex subsp. ballota) con edades elevadas. Experiencias en el monte de Riofrío (Segovia), Investig. Agrar. Sist. Recur. For. (2004) 127-141.

[46] Sonohat G., Balandier P., Ruchaud F., Predicting solar radiation transmittance in the understory of even-aged coniferous stands in temperate forests, Ann. For. Sci. 61 (2004) 629-641.

[47] Valladares F., Light and the evolution of leaf morphology and physiology, Curr. Top. Plant Biol. 4 (2003) 47-61.

[48] Valladares F., Light heterogeneity and plants: from ecophysiology to species coexistence and biodiversity, in: Esser K. et al. (Eds.), Progress in Botany, Springer Verlag, Heidelberg, 2003, pp. 439471.

[49] Valladares F., Allen M.T., Pearcy R.W., Photosynthetic response to dynamic light under field conditions in six tropical rainforest shrubs occurring along a light gradient, Oecologia 111 (1997) 505-514.
[50] Valladares F., Pearcy R.W., The geometry of light interception by shoots of Heteromeles arbutifolia: morphological and physiological consequences for individual leaves, Oecologia 121 (1999) 171-182.

[51] Wagner H.H., Spatial covariance in plant communities: integrating ordination, geostatistics, and variance testing, Ecology 84 (2003) $1045-1057$.

[52] Weiss S.B., Rich P.M., Murphy D.D., Calvert W.H., Ehrlich P.R. Forest canopy structure at overwintering monarch butterfly sites Measurements with hemispherical photography, Conserv. Biol. 5 (1991) 165-175.

[53] Wiens J.A., Ecological heterogeneity: an ontogeny of concepts and approaches, in: Hutchings M.J., John E.A., Stewart A.J.A. (Eds.), The ecological consequences of environmental heterogeneity, Balckwell Science, Cambridge, 2000, pp. 9-31. 